\section{Glycogen in Yeast Form of Paracoccidioides brasiliensis}

Paracoccidioides brasiliensis is the causative agent of South American blastomycosis. McKinnon and Vinelli ${ }^{1}$, and Carbonell et al. ${ }^{2}$, suggested in their histochemical investigations that the yeast form of this fungus may contain glycogen. The present investigation deals with the biochemical identification of glycogen in the yeast form of $P$. brasiliensis. The fungus used (strain No. 8159 of the Instituto Nacional de Tuberculosis, Caracas, Venezuela) was originally isolated from a lymph node in a human systemic infection and cultured on brain heart infusion agar (Baltimore Biological Laboratory) with human blood (10 per cent) and antibiotics (penicillin, 20 units per ml.; streptomycin, $400 \mu \mathrm{g}$ per $\mathrm{ml}$.) at $37^{\circ} \mathrm{C}$. The fungus was eollected on the fifth day of culture, and washed 4 times with distilled water by centrifugation (500 $\mathrm{g}, 5 \mathrm{~min})$. After extracting the lipids by means of a mixture of ethanol and ether (3:1), the fungus, suspended in distilled water, was disintegrated in a Branson sonifier at $20 \mathrm{kc} / \mathrm{s}$ for $20 \mathrm{~min}$. The disruption of the cell material was completed by treatment in a Waring blender for $1 \mathrm{~h}$. The polysaccharide was isolated according to the method of Abdel-Akher and Smith', that is, extraction with boiling water, removal of proteins by trichloroacetic acid, and purification by repeated precipitation from aqueous solution with ethanol. From $7.04 \mathrm{~g}$ of vacuum-dried fungus material, a polysaccharide fraction (126 mg), acetone-soluble lipids (977 $\mathrm{mg}$ ) and acetone-insoluble lipids $(110 \mathrm{mg}$ ) were obtained.

The isolated polysaccharides dissolved easily in water, showing opalescence. A reddish brown colour was produced with iodine. After hydrolysis in $\mathrm{N} \mathrm{HCl}$ for $3 \mathrm{~h}$ in a boiling-water bath, 64 per cent of the weight was liberated as glucose which was determined enzymatically by the combined system of hexokinase and glucose-6-phosphate dehydrogenase ${ }^{4}$. This value was almost equal to that of 65 per cent obtained after the digestion by 'Diazyme' (Miles Chemical Company). 'Diazyme' contains amylase and amyloglucosidase and is used in quantitative determinations of glycogen ${ }^{5}$. After complete hydrolysis by phosphorylase and amyloglucosidase, the ratio of glucose1-phosphate to glucose was determined to bo 10.9 according to the method of Bueding and Hawkins ${ }^{6}$. This result implies that the polyglucose contained in the fungus reprosents glycogen and not starch.

The polysaccharide fraction contained, besides glycogen, other compounds which were demonstrated by chemical analysis. The total sugar content of the dry material, evaluated by the anthrone method ${ }^{7}$ with glucose as standard, was found to be 85 per cent. The material contained $1 \cdot 7$ per cent nitrogen $8,3 \cdot 2$ per cent proteins ${ }^{9}$ with bovine serum albumin as standard, $0 \cdot 4$ per cent total phosphorus ${ }^{10}$, less than 1.2 per cent glucosamine ${ }^{11}$, and less than 2.0 per cent pentoses ${ }^{12}$ with xylose as standard. Ketosugars ${ }^{13}$ and uronic acids ${ }^{14}$ could not be detected.

The results reported here suggested that most of the nitrogen was not derived from glucosamine but probably from proteins. In order to remove the proteins, part of the polysaccharide fraction was treated with 30 per cent potassium hydroxide for $2 \mathrm{~h}$ in a boiling-water bath and purified by repeated precipitation ( 3 times) from aqueous solution with ethanol. This alkali-treated polysaccharide fraction contained as much as 80 per cent glycogen, as found after acid hydrolysis or digestion by 'Diazyme' or phosphorylase. The ratio of glucose-1-phosphate to glucose was $10 \cdot 5$. This alkali-treated polysaccharide fraction contained the following substances: sugars (as glucose), 95 per cent; nitrogen, loss than $0 \cdot 2$ per cent; proteins, less than 0.5 per cent; pentoses, less than 0.5 per cent.

The difference between the glucose content as found by specific enzymatic methods and the total sugar content as obtained by the anthrone method is apparently due to the presence of other sugars. After hydrolysis in $\mathrm{N}$ sulphuric

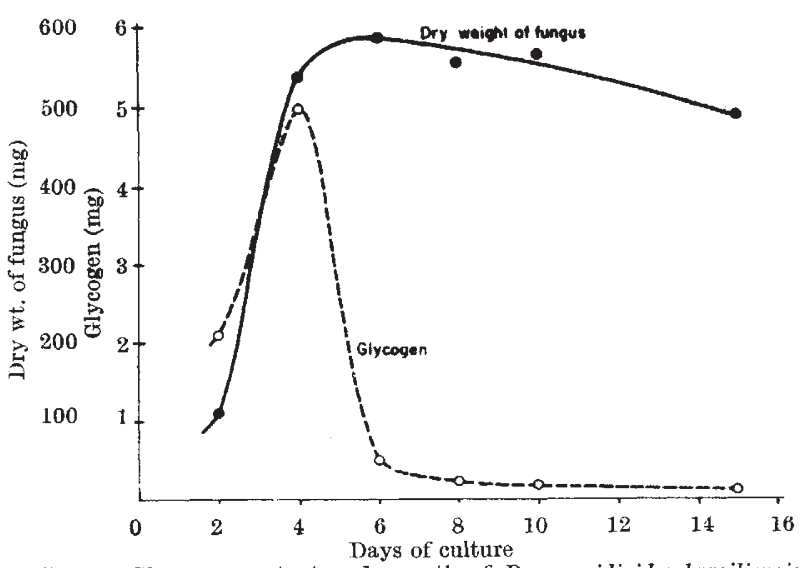

Fig. 1. Glycogen content and growth of Paracoccidioides brasiliensis cultured on blood agar

acid for $4 \mathrm{~h}$ in a boiling-water bath and after neutralization with barium carbonate, mannose was found by paper chromatography, using various solvent systems; phenol ${ }^{15}$, $s$-collidine ${ }^{15}$, and ethyl acotate-water-acetic acid $(3: 3: 1)^{16}$. Mannose may exist in the polysaccharide fraction as mannan in combination with glycogen.

The relationship between glycogen content and age of culture was studied as follows: the fungus, collected after various periods of culture, was washed 4 times with distilled water and, after extraction of lipids, the glycogencontaining fractions were prepared by the method described here. To remove glucose and glucose-6-phosphate, the concentrated fractions were dialysed against cold distilled water for $24 \mathrm{~h}$ instead of treating them with trichloroacetic acid and ethanol. The fractions containing less than $2 \mathrm{mg}$ of polysaccharides were digested with $2 \mathrm{mg}$ of 'Diazyme' at $40^{\circ} \mathrm{C}$ for $2 \mathrm{~h}$ in a total volume of $5 \mathrm{ml}$. of acetate buffer $(0.02 \mathrm{M}, p \mathrm{H} .5 \cdot 0)$. After digestion, the liberated glucose was determined enzymatically. As shown in Fig. 1, the glycogen synthesized during the lag and logarithmic growth phases is consumed rapidly after the onset of the stationary phase. This finding is in agreement with earlier bistochemical results ${ }^{2}$.

We thank Dr. K. Gaede for his advice and Mr. J. Rodriguez for his assistance in the eulture of the fungus.

This work was partially supported by the Research Office of the U.S. Army (grant $D A-A R O-49-092$ ).

FUMINORI KANETSUNA

Luis M. CarboneLI

Departamento de Patología Experimental,

Instituto Venezolano de Investigaciones Científicas, Caracas, Venezuela.

${ }^{1}$ McKinnon, J., and Vinelli, H., An. Fac. Med. Montevideo, 34, 461 (1949).

2 Carbonell, L. M., Castlejón, H., and Pollak, L., J. Histochem. Cytochem., 12, 413 (1964).

${ }^{3}$ Abdel-Akher, H., and Smith, F., J. Amer. Chem. Soc., 73, 994 (1951).

4 Slein, M. W., in Methods of Enzymatic Analysis, edit. by Hans-Uirich Bergmeyer, 117 (Academic Press, New York and London, 1963).

John , J. D., and Fusaro, R. M., Anal. Biochem., 5, 379 (1963).

Guding . A . 26 (1964); 9, 115 (1964).

Bueding, E., and Mawin, E. H., Anal. Chem, 25, 1656 (1953).

"Scott, T. A., and Melvin, K. H., Anal. Chem., 25,

Jowr, O. H., Roscbrough, N., J., Farr, A., and Randall, R. J., J. Biol. Chem., 193, 265 (1951).

${ }^{10}$ Fiske, C. H., and Subbarrow, Y., J. Biol. Chem., 66, 375 (1925)

11 Belcher, R., Nutten, A. J., and Sambrook, C. M., Analyst, 79, 201 (1954)

12 Fernell, W. R., and King, H. K., Analyst, 78, 80 (1953).

13 Bryson, J. L., and Mitchell, T. J., Nature, 167, 864 (1951).

14 Gee, M, and McCrendy, R. M. Anal. Chem., 29, 257 (1957).

is Partridge, S. M., Biochem. J., 42, 238 (1948).

is Jermyn, M. A., and Isherwood, F. A., Biochem. J., 44, 402 (1949).

\section{PHYSIOLOGY}

\section{Plasma Growth-hormone Levels in Chronic Starvation in Man}

Вотн fasting and induced hypoglycaemia aro powerful stimuli to secretion of growth hormone in $\operatorname{man}^{1-3}$, but the offect of prolonged starvation on secretion of growth 